Finley, W. H., Finley, S. C., and Monsky, D. (1971). An extra small metacentric chromosome in association with multiple congenital abnormalities. Fournal of Medical Genetics, 8, 381-383.

Hamilton, C. R., Jr., Henkin, R. I., Weir, G., and Kliman, B. (1973). Olfactory status and response to Clomiphene in male gonadotropin deficiency. Annals of Internal Medicine, 78, 47-55.

Hulten, M., Lindsten, J., Fraccaro, M., Mannini, A., and Tiepolo, L. (1966). Extra minute chromosome in somatic and germ-line cells of the same person. Lancet, 2, 22-24.

Kallmann, F. J., Schonfeld, W. A., and Barrera, S. E. (1944). The genetic aspect of primary eunuchoidism. American fournal of Mental Deficiency, 48, 203-236.

McKusick, V. A. (1971). Mendelian Inheritance in Man, 3rd ed. Johns Hopkins Press, Baltimore.

Morsier, G., de (1954). Etudes sur les dysraphies crânio-encephalliques. I. Agénésie des lobes olfactifs (télencéphaloschizis latéral), et des Commissures calleuse et autérieure (telenchephaloschizis médian). La dysplasie olfacto-génitale. Schweizer Archiv für Neurologie und Psychiatrie, 74, 309-361.

Naftolin, F. G., Harris, G. W., and Bobrow, M. (1971). Effect of purified luteinizing hormone releasing factor on normal and hypogonadotropic anosmic men. Nature, 232, 496-497.

Santen, R. J. and Paulsen, C. A. (1973). Hypogonadotropic eunuchoidism. I. Clinical study of the mode of inheritance. Fournal of Clinical Endocrinology and Metabolism, 36, 47-54.

Smith, K. D., Steinberger, E., Steinberger, A., and Perloff, W. (1965). A familial centric chromosomic fragment. Cytogenetics, 4, 219-226.

Ventruto, V., Rossi, A., and Sebastio, L. (1973). Frammento cromosomico metacentrico soprannumerario in psoriasico fenotipicamente normale (47,XY, ? +). Minerva Medica, 64, 1624-1632.

Zarate, A., Kastin, A. J., Soria, J., Canales, E. S., and Schally, A. V. (1973). Effect of synthetic luteinizing hormone-releasing hormone (LH-RH) in two brothers with hypogonadotropic hypogonadism with anosmia. Fournal of Clinical Endocrinology and Metabolism, 36, 612-614.

\title{
A probable case of mutation in Huntington's disease*
}

\begin{abstract}
Summary. A patient is described in whom Huntington's disease was diagnosed at the age of 34 years. No evidence of the disorder was found in either parent. Their parentage of the alleged mutant could not be excluded from a study of the inheritance of 25 genetic markers.
\end{abstract}

It is rare for signs of Huntington's disease to appear in offspring before it manifests itself in one of the living parents. When such a case occurs, it is reasonable to suspect a mutation. Because of the possibility of very late onset of symptoms, few cases have been reported in which the parents of the alleged mutant are both alive. For such reasons, Reed and Neel (1959) do not believe that specific instances of mutation in the disorder can be demon-

\footnotetext{
* This work was supported in part by a grant from the National Health and Medical Research Council of Australia.
}

strated. It follows that an accurate estimate of the very low mutation rate is impossible until present diagnostic techniques improve. Palm (1973) has briefly reviewed the evidence against the gene being maintained in the population by new mutations.

We wish to describe a probable mutant who came to light in the course of an ascertainment of families affected with Huntington's disease in the state of Victoria.

\section{Case report}

The propositus was born in a village in Calabria, Italy, in 1935. At the age of 34 years, he began to develop involuntary movements. He was at that time a successful restaurant and store owner and was a highly respected migrant in a small town near Melbourne. The movements began first in his right leg and later spread to his abdomen, right arm, head, neck, and shoulders. These symptoms were followed by increasing defects in memory and inability to carry on the conduct of his business. He took up employment in a real estate agency and over a period of some 14 months deteriorated to a packer in a vegetable market. For 12 months before presentation early in 1973, he was unemployed.

By the time of referral for investigation, his choreiform movements and dementing process were pronounced. The diagnosis of Huntington's chorea was made by two independent neurological opinions, and pneumoencephalographic examination confirmed atrophy of the caudate nucleus and associated apparent dilatation of the third ventricles with generalized cortical atrophy (Figs. 1 and 2).

There is no family history of Huntington's disease. His father was born in 1911 and his mother was born in 1913, both being of Calabrian descent. The propositus has four sibs, being younger sisters born in 1936, 1937, 1942, and 1947. Inquiries were made into the extended family and in the village. Within living memory, there was no recollection of anyone with similar symptoms part from a female second cousin who, at the age of 12 years, developed rheumatic fever and subsequently suffered from Sydenham's chorea, but had had no recurrence of choreiform symptoms.

Examination of the parents in Melbourne produced no evidence of Huntington's disease. The father was working as an orderly in a geriatric hospital and had been a professional soldier, being home only for short periods during the second World War. The question of the biological parentage of the propositus was investigated by the use of 25 genetic markers in saliva, red blood cells, and plasma (Table). No hereditary incompatibility was detected.

\section{Discussion}

For a mutation to be acceptable, Stevens and Parsonage (1969) have laid down four criteria:

(i) The disease being investigated must have the cardinal features of Huntington's disease-namely, 


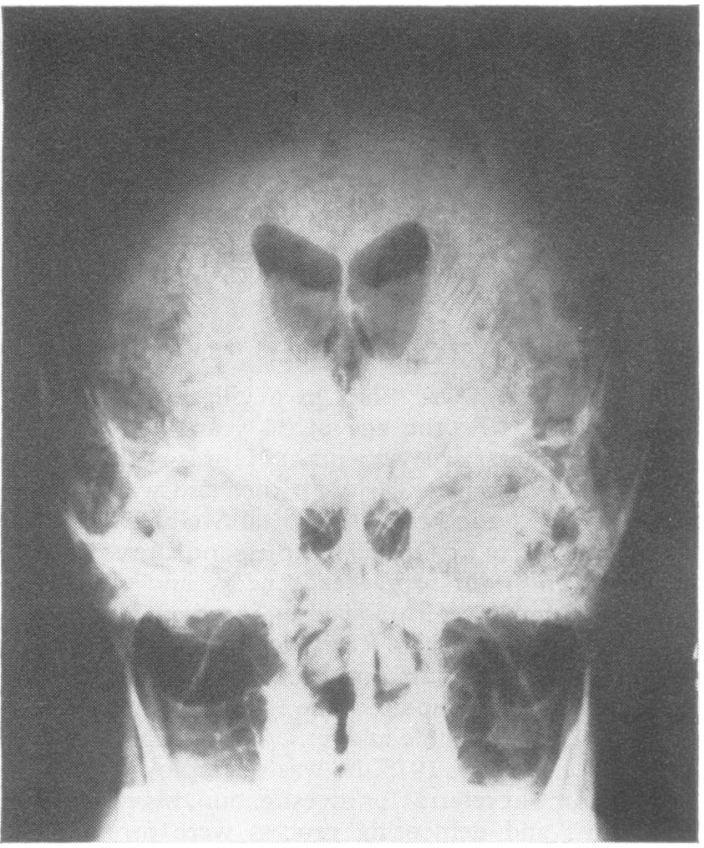

Fig. 1. Pneumoencephalogram: anteroposterior view.

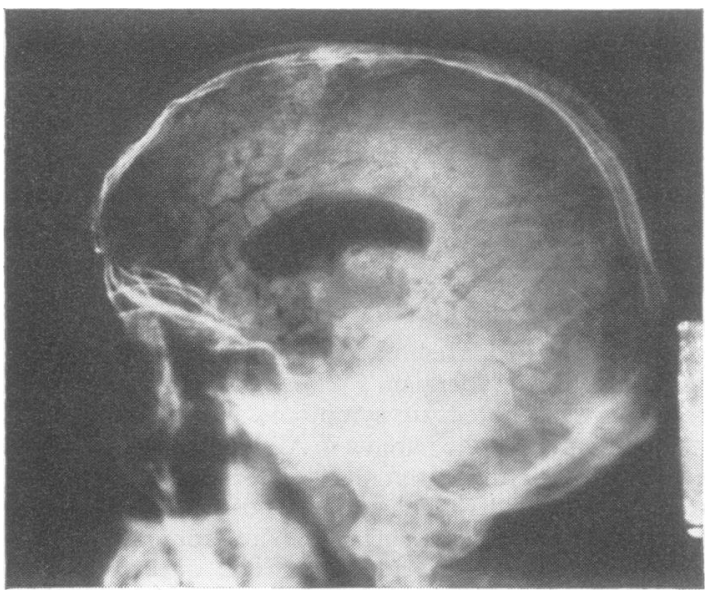

Fig. 2. Pneumoencephalogram: lateral view.

progressive choreoathetosis or rigidity, dementia, and autosomal dominant inheritance (genocopies, such as that described by Cederbaum et al (1971), should be excluded). The latter is important since the disease produced by the mutation should be shown to occur in more than one generation.

(ii) Both parents of the propositus must have

\begin{tabular}{|c|c|c|}
\hline Mother & Father & Propositus \\
\hline $\begin{array}{l}\text { A }_{2} \\
\text { CCDee } \\
\text { MMss } \\
\text { P1- } \\
\text { Lu(a-b+) } \\
\text { K- } \\
\text { Fy(a + b-) } \\
\text { Jka }+ \\
\text { Co b- } \\
\text { Se } \\
\text { Le } \\
\text { ADA 1 } \\
\text { AK 1 } \\
\text { PGD A } \\
\text { ACP }{ }_{1} \text { BA } \\
\text { GPT } 2-1 \\
\text { PGM } \\
\text { PGM } 1 \\
\text { Hp 2-2 } \\
\text { Tf CC } \\
\text { C3 S } \\
\text { E } \\
\text { Gm } \\
\text { Gnv } 1+2-3+5+) \\
\text { BGP I }\end{array}$ & 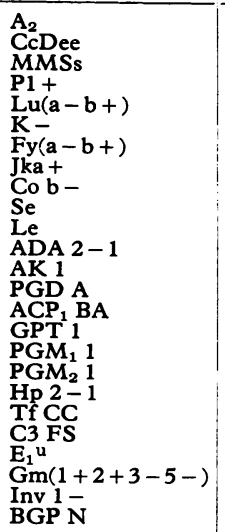 & 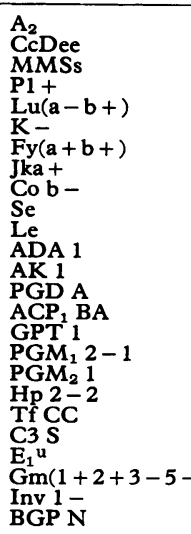 \\
\hline
\end{tabular}

lived to such an age that it can be reasonably assumed that the disease would have appeared hade they carried the abnormal gene.

(iii) Sufficiently reliable information about the health of both parents must be obtained to ensure their freedom from the disease.

(iv) The apparent mutant must be the offspring of both the alleged parents and not the issue of an unknown parent who bore the abnormal gene.

The present case cannot fulfil the requirement of dominant autosomal transmission in criterion (i) because the children of the propositus were born in 1961 and 1972. This deficiency was counterbalanced by the ability to examine personally both parents, thus meeting criterion (iii) and overcoming the common problem-noted by Reed and NeeB (1959) - of having to rely upon other than direct. observation. It is virtually impossible for a single person to examine the three generations of a family (unaffected parents, supposed mutant, and affecteos offspring) ideally envisaged by the requirements 0 The only other area of possible dispute would be the ages of the parents; it can be argued that Hunting ton's disease could still affect one of them. There? is a small chance of this eventuality occurring, sinces cases having an age of onset up to 75 years have been reported in Norway (Ørbeck and Quelprud, 1954). In Victoria the latest onset of symptoms found was at 63 years of age (Brackenridge andk Teltscher, 1975).

As the father of the propositus was a professiona soldier who was seldom home, it was necessary to exclude illegitimacy. This was done to a high degree of probability by using 25 genetic markers $\stackrel{\vec{D}}{0}$ 
Unfortunately it was not possible to estimate the probability of excluding parentage because phenotype frequencies for many of the polymorphisms have not been reported for southern Italy. The present case bears some similarities to two Norwegian sisters, whose apparently unaffected parents were aged 62 and 64 years at the time of reporting (Haugerud, 1968), and whose red-cell antigens in 8 systems provided no evidence for excluding parentage. The alleged mutants both had histories of chronic progressive chorea.

The authors wish to thank Dr J. R. B. Ball for referring the patient and $\mathrm{Mr}$ J. Case, Mr D. N. Propert, and $\mathrm{Mr}$ A. J. Sheehy for typing the saliva and blood samples.

\section{Edmond ChiU and C. J. BRackenRIDGe Department of Psychiatry, University of Melbourne, Royal Melbourne Hospital, Parkville 3050, Victoria, Australia}

REFERENCES

Brackenridge, C. J. and Teltscher, B. (1975). The estimation of the age at onset of Huntington's disease from factors associated with the affected parent. Fournal of Medical Genetics, 12, 64-69.

Cederbaum, S., Heywood, D., Aigner, R., and Motulsky, A. (1971) Progressive chorea, dementia and acanthocytosis; a genocopy of Huntington's chorea. Clinical Research, 19, 177.

Haugerud, S. (1968). Chronische progressive Chorea bei zwei Schwestern ohne nachweisbare Heredität. Schweizerische medizinische Wochenschrift, 98, 2016-2020.

Ørbeck, A. L. and Quelprud, L. (1954). Setesdalsrykka (chorea progressiva hereditaria). J. Dybwad, Oslo.

Palm, J. D. (1973). Longitudinal study of a preclinical test program for Huntington's chorea. Advances in Neurology, 1, 311-324.

Reed, T. E. and Neel, J. V. (1959). Huntington's chorea in Michigan. 2. Selection and mutation. American fournal of Human Genetics, 11, 107-136.

Stevens, D. and Parsonage, M. (1969). Mutation in Huntington's chorea. Fournal of Neurology, Neurosurgery and Psychiatry, 32, 140-143.

\section{Trigonocephaly and associated minor anomalies in mother and son}

\begin{abstract}
Summary. A mother and her son are described with neonatal trigonocephaly, multiple suture synostosis; shallow orbits; unusual nose; deviation of the terminal phalanges of fingers 1,2 , and 5 ; and broad toes which radiologically may show duplication of the terminal phalanx. Untreated, the condition leads to a disfiguring oxycephaly with hypotelorism.
\end{abstract}

\footnotetext{
* Reprint requests to: N.L.R.. Department of Genetics, Hospital for Sick Children, Toronto, Ontario, Canada.
}

This appears to be the first documented instance of autosomal dominant trigonocephaly. The importance of the minor anomalies in its recognition and its good prognosis are emphasized.

Recent progress in facial corrective surgery has resulted in large numbers of children with craniostenosis being seen in single centres. This growth provides a new opportunity for the study and recognition of increasing numbers of subtypes of craniostenosis. Ultimately this will result in improved counselling for parents and patients. We describe here a mother and her son who are affected by trigonocephaly in association with multiple suture synostosis and other minor anomalies. We are unable to find previous reference to the transmission of trigonocephaly from an affected individual to the offspring.

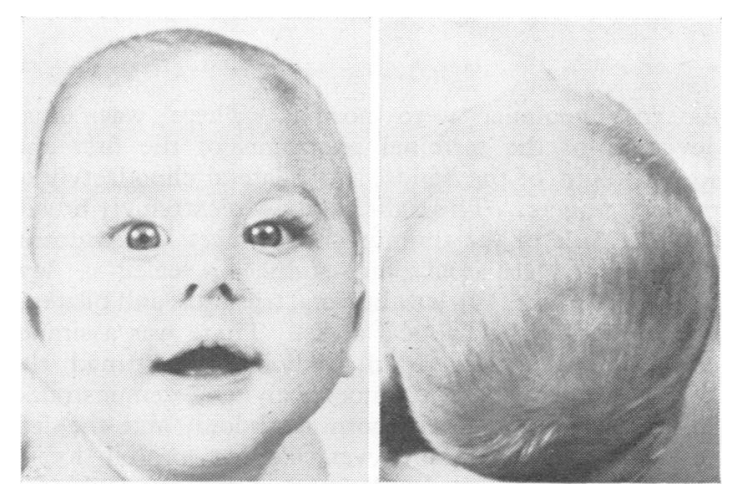

FIG. 1. Propositus at 6 months of age showing prominent metopic ridge, hypotelorism, epicanthic folds, and trigonocephaly.

\section{Case reports}

The propositus was referred to the Hospital for Sick Children in Toronto for evaluation of trigonocephaly. Birth had been complicated by a cephalohaematoma and linear parietal fracture, but development was normal.

On examination at 6 months, length was $71 \mathrm{~cm}(97 \%)$, weight $8500 \mathrm{~g}(80 \%)$, and head circumference $42.5 \mathrm{~cm}$ $(30 \%)$. He had trigonocephaly with a prominent metopic ridge, shallow orbits, epicanthic folds, and minimal ptosis (Fig. 1). The inner canthal, outer canthal, and interpupillary distances were $2.5 \mathrm{~cm}(97 \%)$, $7 \mathrm{~cm}(50 \%)$, and $4 \mathrm{~cm}(3 \%)$, respectively. The nose was hooked with the septum extending below the alae, and the philtrum attached anteriorly on the septum. $\mathrm{He}$ had a large mouth with a down-turned upper lip. 